Case report-Olgu sunumu

http://dx.doi.org/10.7197/1305-0028.1074

\title{
Percutaneous closure of perimembranous and muscular ventricular septal defects in the same session in a pediatric patient
}

\author{
Bir çocuk hastada perimembranöz ve musküler ventriküler septal defektlerin \\ aynı seansta perkütan yolla kapatılması
}

Mehmet Burhan Oflaz*, Hekim Karapınar, Hasan Ali Gümrükçüoğlu, Zekeriya Küçükdurmaz, İbrahim Gül

Departments of Pediatric Cardiology (Assist. Prof. M. B. Oflaz), Cardiology (Assist. Prof. H. Karapınar, MD, Assist. Prof. Z. Küçükdurmaz, MD, Assist Prof. İ. Gül, MD), Cumhuriyet University School of Medicine, TR-58140 Sivas, Department of Cardiology (Assist. Prof. H. A. Gümrükcüoğlu, MD) Yüzüncüyıl University School of Medicine, TR-65040 Van

\begin{abstract}
Ventricular septal defect closure is proposed because of some possible complications such as left heart failure, pulmonary vascular disease, Eisenmenger's syndrome and infective endocarditis. These defects are conventionally closed by surgery in general practice. Percutaneous closure is becoming increasingly common in recent years. While percutaneous closure was first reported in muscular defects, currently it is also used successfully for perimembranous defects. In this paper we presented a pediatric case with a single perimembranous ventricular septal defect detected on transthoracic echocardiography examination. The muscular defect was detected during the intervention and was closed percutaneously in the same session with the perimembranous defect
\end{abstract}

Keywords: Congenital heart disease, ventricular septal defect, percutaneous closure, complication

\section{Özet}

Ventriküler septal defektlerin sol kalp yetersizliği, pulmoner vasküler hastalık, Eisenmenger sendromu ve enfektif endokardit gibi muhtemel komplikasyonları sebebiyle kapatılmaları önerilmiştir. $\mathrm{Bu}$ defektler konvansiyonel olarak cerrahi yolla kapatılmaktadır. Son yıllarda perkütan yolla kapatma giderek yaygınlaşmaktadır. İlk olarak perkütan kapatma müsküler defektler için bildirilmişken günümüzde perimembranöz defektlerde başarılı bir şekilde kapatılabilmektedir. $\mathrm{Bu}$ yazıda transtorasik ekokardiyografide tek perimembranöz ventriküler septal defekt tespit edilen, perkütan kapatma işlemi sırasında müsküler septumda ikinci bir defekt saptanması ile aynı seansta perkütan yolla her iki defektin kapatıldığı bir çocuk olgu sunulmuştur.

Anahtar sözcükler: Konjenital kalp hastalığı, ventriküler septal defekt, perkütan kapatma, komplikasyon

Geliş tarihi/Received: August 19, 2011; Kabul tarihi/Accepted: December 05, 2011

\section{*Corresponding author:}

Dr. Mehmet Burhan Oflaz, Çocuk Kardiyolojisi Bilim Dalı, Çocuk Sağlığı ve Hastalıkları Anabilim Dalı, Cumhuriyet Üniversitesi Tıp Fakültesi, TR-58140 Sivas. E-mail: mburhanoflaz@gmail.com

\section{Introduction}

Closure was recommended for ventricular septal defects (VSD) because of the possible complications like left cardiac failure, pulmonary vascular disease, Eisenmenger Syndrome and infective endocarditis [1]. These defects were closed conventionally by surgical methods. But visualisation and closure via surgical methods are hard in VSDs, 
especially in cases with mucular VSDs, because of the trabeculated morhology of the septum. This anatomical structure increases the mortality and residual defect incidences [2]. Currently percutaneous closure of these defects is applied widespreadly troughout the world. Although percutaneous closure was the first choice surgical procedure for muscular defects, it is also preferred for perimembranous defects contemporarily [3-6]. In this study, we presented a pediatric patient with perimembraneous and muscular VSDs whom treated via transcatheter approach.

\section{Case report}

We diagnosed perimembranous VSD at a 7 year-old boy that refered to our center for transthoracic echocardiography (TTE). The defect diameter was $4 \mathrm{~mm}$ and aortic rim was $3 \mathrm{~mm}$ without aortic insuefficiency. We planned transeosaphageal echocardiography (TEE) and transcatheter closure. We performed TEE in the catheter laboratory under general anesthesia and revealed a $4 \mathrm{~mm}$ defect and a suefficient aortic rim. Left ventriculography revealed a single perimembranous defect with similar dimesions in TTE. Pulmonary artery systolic pressure was $31 \mathrm{mmHg}$, diastolic pressure was $14 \mathrm{mmHg}$ and mean was $22 \mathrm{mmHg}$. Qp/Qs was 2.1. We could not able to cross to the right ventricle trough the defect by diagnostic LIMA and right Judkins catheters over a 0.038 inch guiding wire so we tried with 0.038 inch guiding wire coated with PTFE. Unexpectedly we crossed to right ventricle via the mid-muscular septum, and reached to the defect's right ventricular ostia with delivery catheter via the venous approach. We revealed a 2 $\mathrm{mm}$ mid-muscular defect by the opacification of the left ventricle and after that the right ventricle (Figure 1). We deployed the smallest VSD device $4 \mathrm{~mm}$ Amplatzer Muscular VSD device (AGA Medical Corp., Golden Valley, Minnesota, USA). There was no residual shunt (Figure 2). Than we deployed another device onto the perimembranous defect (6 mm Amplatzer Perimembranous VSD device, AGA Medical Corp., Golden Valley, Minnesota). We revealed a minimal residual shunt by the ventriculography but not with TEE (Figure 3). The devices' relation with aortic valve and the other neighbour tissues were found normal. No bradycardia, conduction block findings, pause or hemodynamic problems was seen during the follow-up in the hospital. The next day, 1st, 3rd and 6th month ECG and 24 hour Holter monitoring revealed the normaly sinus rhythm, and control TTE was found normal.

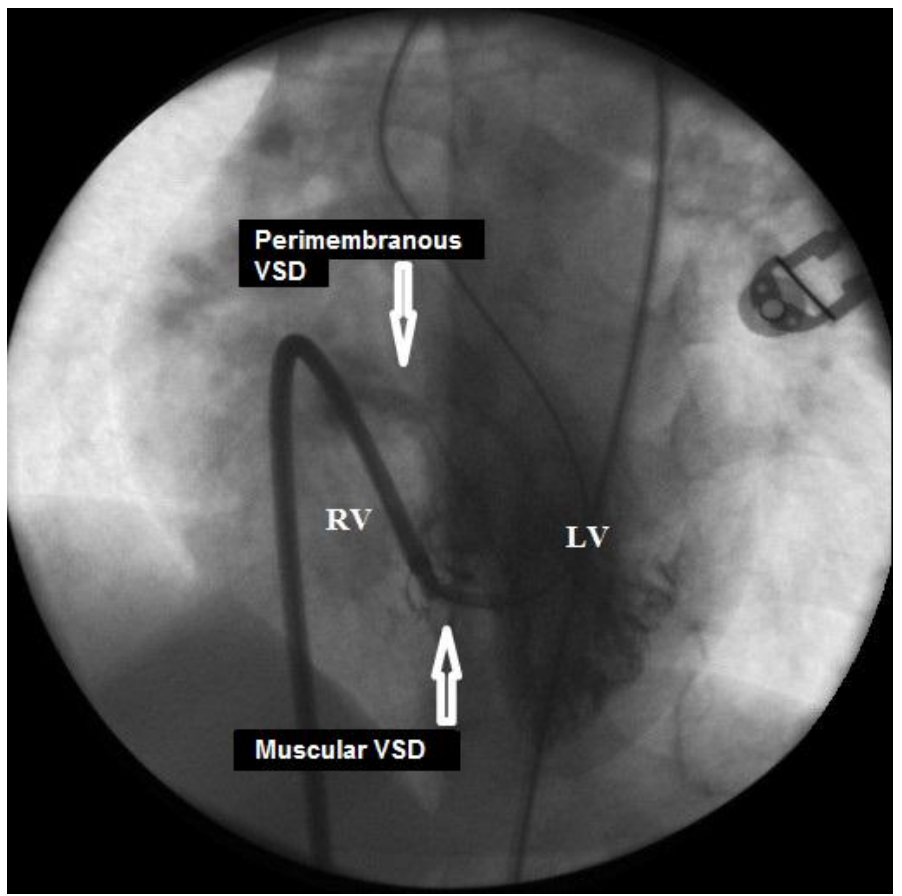

Figure 1. Left ventriculograhy performed via the right ventricular ostia of the muscular VSD. 


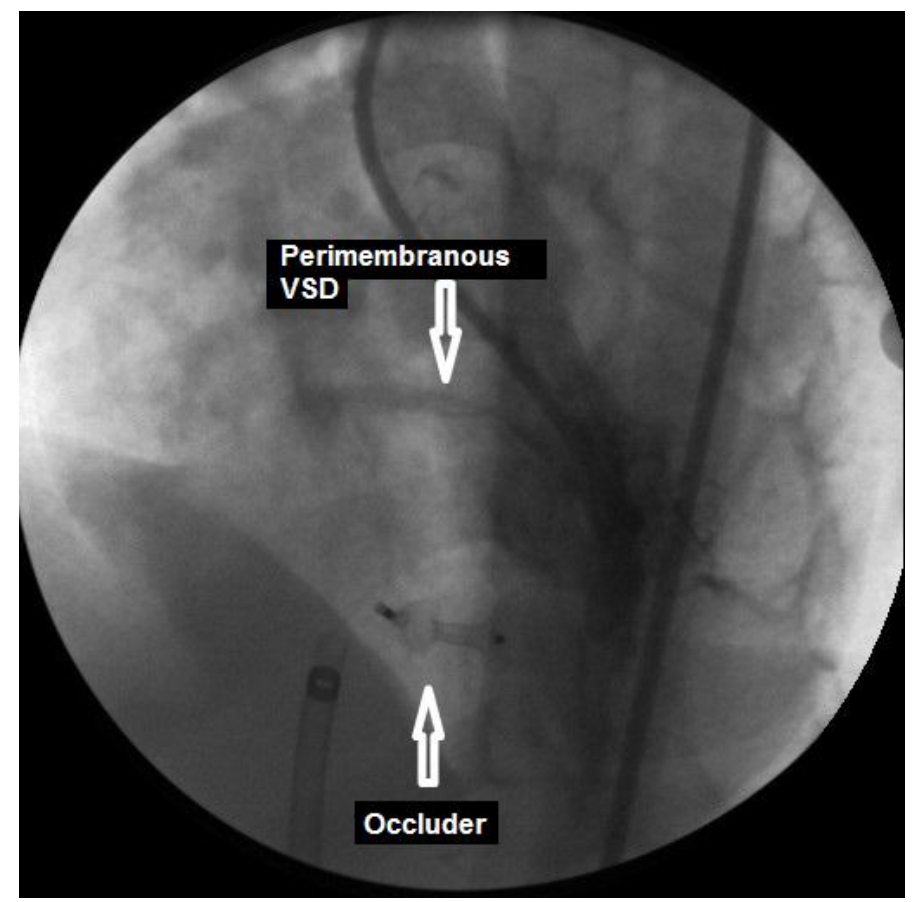

Figure 2. Successfully deployed device on the muscular VSD and the opacification of the left ventricle via the perimembranous VSD.

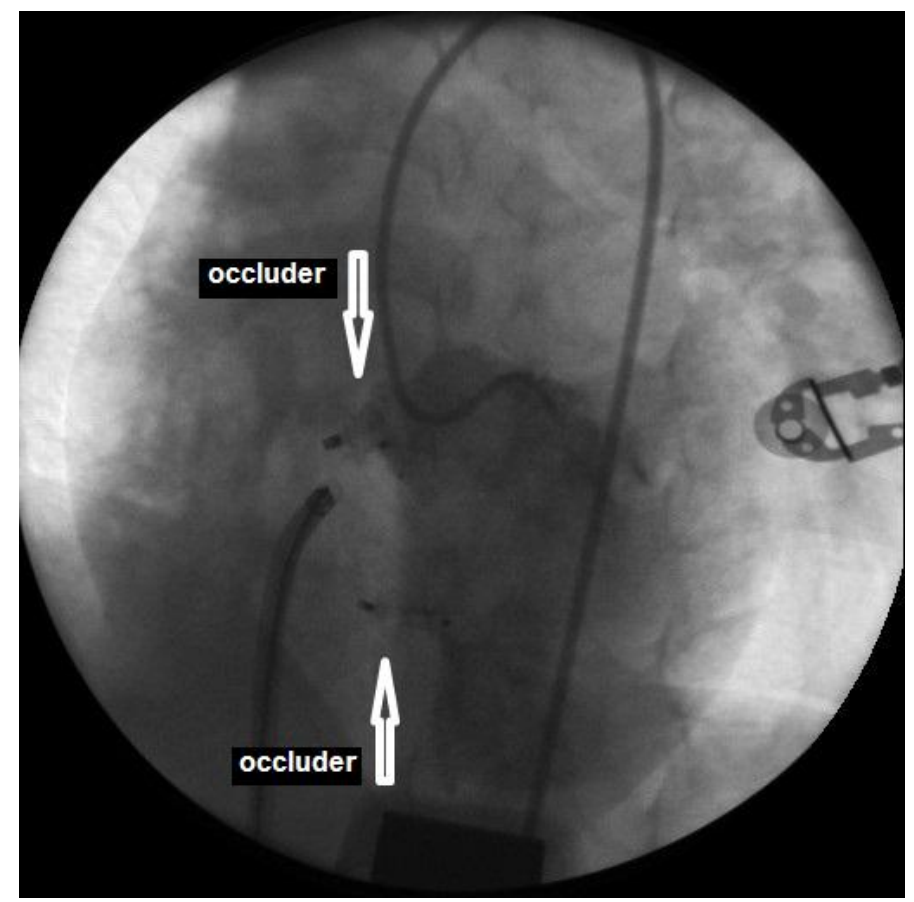

Figure 3. Successfully deployed devices on the muscular and perimembranous VSDs and no residual shunt.

\section{Discussion}

Currently, muscular VSDs are closed via the transcatheter approach [3-4]. But transcatheter closure of perimembranous VSDs were limited in number because of the 10-30\% aortic insuefficiency, AV block and device embolisation [5-6]. Asymmetric perimembronous VSD closure device was produced to prevent aortic insuefficieny but the 
AV block risk was found to resist also with this novel device [5-6]. Device producer recommended to decide via the mean diameter after two plan demonstration of the defect, because of its eliptical morphology and not to perform oversizing. Later studies confirmed this recommendation as truth [7]. But this situation increases the embolisation risk and the operation time.

Incidental imagination of a muscular VSD during the procedure, which was not demonstrated by TTE and ventriculography make this case more interesting. Probably functional closure of the defect during the systole caused this situation. Therapeutic guides say nothing about the closure of small VSDs that do not cause complications like a significant shunt, aortic insuefficiency and infective endocarditis [1]. This situation has two reasons; the underexpected effectiveness of the closure and the cost and possible complications.

Muscular VSD closure is easier than the perimembranous VSD closure and AV block risk, that is the most frequent complication, is very low [3-4]. Other frequent complications are about the insertion sites [3-4]. In our case, muscular VSD was diagnosed after the insertion of arterial and venous sheaths and the guidewire so muscular VSD closure did not carry an additional vascular risk. Operation time is also another important issue but additional time and radiation exposure for the closure of the muscular VSD after performing the arteriovenous loop was limited. Related literature about this issue is limited. Waight et al. [8] reported successfull closure of multiple VSDs in 3 patients. In our routine clinical application we also don't close these single small VSDs. But this small VSD was diagnosed incidentally during the procedure. So we decided to close both defects because of the possible benefits, low additional complication risk after the wish and the consent of the guardian.

Multiple VSDs can be percutaneously closed. Device usage with similar size of the defect decreases the AV block risk whereas increases the embolisation risk and lengthen the operation time. There is not enough data for the closure of multiple defects in the literature. Both defects might be closed like our case or only the diagnosed one might be closed and the incidentally diagnosed one might be followed-up. We think that the decision of the family carry importance about the closure decision.

\section{References}

1. Baumgartner H, Bonhoeffer P, De Groot NM, de Haan F, Deanfield JE, Galie N, Gatzoulis MA, Gohlke-Baerwolf C, Kaemmerer H, Kilner P, Meijboom F, Mulder BJ, Oechslin E, Oliver JM, Serraf A, Szatmari A, Thaulow E, Vouhe PR, Walma E; Task Force on the Management of Grown-up Congenital Heart Disease of the European Society of Cardiology (ESC); Association for European Paediatric Cardiology (AEPC). ESC Guidelines for the management of grown-up congenital heart disease (new version 2010). Eur Heart J 2010; 31: 2915-57.

2. Serraf A, Lacour-Gayet F, Bruniaux J, Ouaknine R, Losay J, Petit J, Binet JP, Planché C. Surgical management of isolated multiple ventricular septal defects. Logical approach in 130 cases. J Thorac Cardiovasc Surg 1992; 103: 437-42.

3. Holzer R, Balzer D, Cao QL, Lock K, Hijazi ZM; Amplatzer Muscular Ventricular Septal Defect Investigators. Device closure of muscular ventricular septal defects using the Amplatzer muscular ventricular septal defect occluder: immediate and mid-term results of a U.S. registry. J Am Coll Cardiol 2004; 43: 1257-63.

4. Hijazi ZM, Hakim F, Al-Fadley F, Abdelhamid J, Cao QL. Transcatheter closure of single muscular ventricular septal defects using the Amplatzer Muscular VSD Occluder: Initial results and technical considerations. Cathet Cardiovasc Interv 2000; 49: 167-72.

5. Thanopoulos BD, Tsaousis GS, Karanasios E, Eleftherakis NG, Paphitis C. Transcatheter closure of perimembranous ventricular septal defects with the 
Amplatzer asymmetric ventricular septal defect occluder: preliminary experience in children. Heart 2003; 89: 918-22.

6. Fu YC, Bass J, Amin Z, Radtke W, Cheatham JP, Hellenbrand WE, Balzer D, Cao QL, Hijazi ZM. Transcatheter closure of perimembranous ventricular septal defects using the new Amplatzer membranous VSD occluder: results of the U.S. phase I trial. J Am Coll Cardiol 2006; 47: 319-25.

7. Bentham JR, Gujral A, Adwani S, Archer N, Wilson N. Does the technique of interventional closure of perimembranous ventricular septal defect reduce the incidence of heart block? Cardiol Young 2011; 21: 271-80.

8. Waight DJ, Bacha EA, Kahana M, Cao QL, Heitschmidt M, Hijazi ZM. Catheter therapy of Swiss cheese ventricular septal defects using the Amplatzer muscular VSD occluder. Catheter Cardiovasc Interv 2002; 55: 355-61. 